研究論文

\title{
バワーズの「持続可能な文化に向けての 環境教育」論の批判的検討
}

今村 光章 $^{1} \cdot$ 五十嵐 有美子 $2 \cdot$ 石川 聡子 $^{3} \cdot$ 井上 有一 ${ }^{2}$

下村 静穂 $^{4} \cdot$ 杉本 史生 ${ }^{5} \cdot$ 諸岡 浩子 6

1 : 岐阜大学 2 : 京都精華大学 3 : 大阪教育大学 4 : 奈良女子大学大学院

5 : 京都大学大学院 6 : くらしき作陽大学

\section{What is "Environmental Education for an Ecologically Sustainable Culture" ?: A Critical Analysis of C. A. Bowers' Major Propositions}

\author{
Mitsuyuki IMAMURA¹, Yumiko IGARASHI², Satoko ISHIKAWA 3 , Yuichi INOUE², \\ Sizuho SHIMOMURA ${ }^{4}$, Fumio SUGIMOTO ${ }^{5}$, Hiroko MOROOKA ${ }^{6}$ \\ 1: Gifu University 2: Kyoto Seika University 3: Osaka Kyoiku University \\ 4: Graduate School of Nara Women's University \\ 5: Graduate School of Kyoto University 6: Kurashiki Sakuyo University
} (受理日 2010年1月 8日)

This paper explores C. A. Bowers' main thesis: "environmental education for an ecologically sustainable culture", and tries to determine how the thesis is important in the theoretical effort to develop Education for Sustainability (EfS). The critical analysis centers on Bowers' three major propositions: (1) the radical criticism addressed to modern Western orthodoxies in terms of their compatibility with ecological sustainability; (2) the "reactionary" position against the unchallenged belief supporting the idea of "progress" with a particular emphasis on technological innovation; and (3) Bowers' peculiar "holism”, which largely denies individualism and liberalism. These three propositions clearly separate Bowers' position from the mainstream ideas of environmental education. Bowers' argument, though with quite a few important flaws, serves as a good reference in trying to work out alternative approaches to environmental education helping us to reach a sustainable society.

Key words: autonomous individual, progressionism, modern orthodoxies, biotic community, indigenous traditions

\section{I 問題の所在}

地球環境問題の深刻化が叫ばれる昨今、持続可 能な社会を構築することは喫緊の課題である。こ の課題を解決するためには、どのような社会シス テムや文化、価值観やライフスタイルに特徴づけ
られる未来社会を持続可能な社会として構築する かについて、具体的な見通しが必要である。

一方、持続可能な社会を構築する環境教育の教 育実践が鋭意継続されているが、環境教育の理論 構築においても、持続可能な社会の構想は避けて 通れない課題となりつつある。持続可能性の高い

\section{問い合わせ先 テ501-1193 岐阜市柳戸1-1 岐阜大学教育学部 今村光章}

E-mail: imamura@gifu-u.ac.jp 
未来社会のあり方をどのように見通すかによっ て、環境教育を構想し実践する方向が大きく左右 される。ところが、環境教育が実現すべき持続可 能性の高い社会と文化の状況とはどのようなもの かを明らかにすることは重要な課題でありなが ら、環境教育の分野では十分に論じられてこな かった。

しかしながら、これらの問題に対して、Chester A. Bowers（1935－）は、持続可能な社会状況に 言及して、環境教育を構想している。彼は環境教 育の基礎理論分野における数少ない研究者の一人 であり、媣い含蓄のある数多くの著作を送り出し ている。その理論は、詳細に検討することで、環 境教育の理論に有意義な示唆を得られるものであ る。

本論文では、上記の課題を念頭に、Bowersの 「エコロジカルな意味での持続可能な文化に向け ての環境教育 (environmental education for an ecologically sustainable culture)」論の意義を確 認し、それに批判的考察を加えたい。以下、 Bowersをバワーズと表記し、主として1990年代 に展開されたバワーズの環境教育に関する上記の 論を総じて「持続可能な文化に向けての環境教 育」論と略記する。

「持続可能な文化に向けての環境教育」論は、現 代社会で主流を占める一般的な環境教育論の視座 と射程を根本的に異にする。詳しくは後に述べる が、その基本的な主張は次の三点に整理できる。

第一に、現在の経済発展と開発、および、現代 の西洋的文化と社会が持続することを当然視しな い。現代社会の文化的な微調整ではなく、根底か らの変革や妥協のない価值観の変更が必要だと主 張して、エコロジカルな意味で持続可能な人間社 会の文化に言及し、「持続可能な文化」を創造す る環境教育論を展開していること。

第二に、科学技術の進歩と産業社会の発展を自 明視する考え方に異を唱える保守的な反「進歩 (progress)」論を唱えていること。

第三に、デカルト的二元論、個人主義、および、 自由主義の部分的否定を伴う独自の「ホリス ティック (holistic)」な視点を持ち、自立・自律
した個人への肯定的評価に批判的な目を向けてい ること。

なお、バワーズの「持続可能な文化」や「進歩」 「ホリスティック」といった用語は、独自の意味 で使われており、本稿では括弧を付しておく。

上記の特徴をもつ「持続可能な文化に向けての 環境教育」論は、後述するような難点をかかえて いるが、逆にかえって、基礎研究として、環境教 育に関する理論的考察を深める契機となるものと 言える。

以下、本稿においてはまず、バワーズの基本的 な立場と業績の概要を、環境教育分野を中心にし て確認する（II）。次いで、「持続可能な文化」論、 反「進歩」論、および「ホリスティック」論につ いて、議論を整理する（III）。最後に、バワーズ の論を評価しつつも批判的検討を加える（IV)。 II はIII ならびにIVにおける議論の前提として必要 であるが、こうした整理を行った国内の文献は見 当たらない。

\section{II バワーズの基本的立場と業績の概要}

\section{1. バワーズの基本的立場}

バワーズは、フーコー (Foucault, M : 1926 1984）の思想に強く影響されており、デューイ (Dewey, J : 1859 - 1952) やロジャーズ (Rogers, C. R：1902-1987）などの教育理論を踏まえる 教育哲学研究者である（教育思想史学会 2000）。 エコロジカルな批判的考察においては、ベイトソ ン（Bateson, G : 1904 - 1980）の影響を受けてい る (Bowers 1993b)。

バワーズの基本的なスタンスは、教育において 隠されていた価值観を暴きだし、当然視されてい た思考法を批判するところにある。一方では、科 学的進歩や技術合理性、「おおいなる物語」に対 する信仰を批判する。他方、主体形成という大義 名分を持った教育の理論一すすなち自立・自律 した個人の育成が可能であり、しかも、それを遂 行すべきとする理論——をポストモダン的な発想 から批判する。そのような意味で、彼は「ポスト リベラルな教育理論」(教育思想史学会 2000) を 展開しているとみなされている。 
バワーズの研究領域は幅広く、教育や生態系の 問題ばかりではなく、現代の問題含みの社会状況 や文化的な側面、価值観、制度や規範、道德的判 断、知性や創造性、コンピュータ、言語、情報に も及んでいる。なるほど射程は広いが、バワーズ の思考法は、主流や正統派とされるものの見方に 懐疑的で異議を申し立てるという意味で、徹頭徹 尾「批判的 (critical)」である。

同時に、重大な疑問を差し挟まれることなく当 然視されている文化や価值観が、現代社会の諸問 題を生み出していると省察している。その意味 で、バワーズは「反省的 (reflective)」でもある。 新たな科学技術や文明が問題解決をもたらすとい う技術楽観主義には立たない。思想の根底にある 根源的なるものに反省の目を向けている。彼は、 現代の社会と文化に対する批判と反省とを併せ持 つという意味で、徹底的に「批判的 =反省的 (critical and reflective)」な思考をめぐらせてい る。

当然のことながら、バワーズは環境教育にも 「批判的=反省的」な目を向けている。バワーズ の著作『コンピュータを疑え』（Bowers 2000） の翻訳者の杉本卓が「訳者あとがき」で述べた表 現を借りれば、「彼（バワーズ）の仕事の特徵を 一言で述べるなら、環境と文化の持続可能性とい う観点から教育のあり方について梁く考察すると いうところにある」。杉本は、そのような「彼の 仕事はいわゆる『環境教育』という分野とは少々 異な」り、「自然や環境について学ぶこととか、 環境を維持・回復するために何をなすべきかを学 ぶ」といった「狭義の『環境教育』ではなく、教 育のあり方、さらには人間や社会のあり方につい て、環境や生態という視点から根本的に問い直そ うとしている」（杉本 2003）と指摘する。

環境教育についての考察においては、バワーズ は、基本的に批判的教育学 (critical pedagogy) の影響を受けている。彼は、社会的再生産装置と しての近代学校教育システムのなかで、環境問題 を生み出した母体となる産業社会の再生産を行い ながら、一方で環境問題を解決する持続可能な社 会へと社会を変革するシステムとしての役割が環
境教育に期待されていると指摘する(今村 2003)。 そして、現代文化に呪縛された学校という文化的 再生産装置の中で、文化の基盤を問うという契機 を与えられたことで、環境教育は「ダブルバイン ド (二重拘束) 状態」に陥っていて、実効性を発 揮するほどには効果がない状況にあると見ている (Bowers 1993b)。この状況から脱出するには、 学校が潜在的に産業社会の再生産システムとして の社会的機能を果たしている点を学校教員や大学 教員が明確に自覚し、産業社会を変革する機能を 環境教育に期待しなければならないという (Bowers 1995b)。すなわち、環境教育の「ダブ ルバインド」状況を脱却するための理論が「持続 可能な文化に向けての環境教育」論であるともい える。

しかしながら、バワーズは、依拠している批判 的教育学そのものでさえ、人間の解放や個人のエ ンパワーメントを普遍的に善なるものと見なして いる点、印刷され、紙に書かれた観念的な知識が 唯一妥当なものであると考えている点、個人主義 的で「進歩」を善なるものと見なしている点で難 点があると考えている(Bowers 2001)。バワーズ の環境教育に関する考察の端緒は、1991年の『ト ランペッター (Trumpeter)』誌に掲載された「教 育的自由主義の人間中心主義的な基盤：いくつか の批判的関心」(Bowers 1991）にさかのぼる。 この論文で彼は、批判的な環境教育のカリキュラ 厶理論が、人間中心主義的であるばかりか、階 級・人種・ジェンダーの問題を優先しているた め、エコロジカルな問題の緊急性を見落としてい ると断罪し、しかも、「ホリスティック」な視点 が欠けていると批判している（Bowers 1991）。

オーストラリアの代表的な環境教育学者である フィエン（Fien, J : 1951 - ）は、上記のバワー ズの論文における批判を強く意識して、『環境の ための教育一批判的カリキュラム理論と環境教 育』(Fien 1993)を著している。フィエンがバワー ズを強く意識していたことからも、バワーズの 「批判的=反省的」思考の鋭さとその影響力がう かがい知れるだろう。

加えて言えば、バワーズは、環境教育の実践で 
はなく、理論に興味を持っているところに特徴が ある。彼の著作のなかでは、環境教育の具体的な 教育方法や教育内容、現実的なカリキュラムや教 材について、深い洞察は見当たらない。直接的に 環境教育の教育実践に結びつく有意義な指摘も見 当たらない。しかし、教育実践にまったく興味が なかったのではなく、その興味関心は、子どもた ちを教える教員養成に向いていたと考えられる。

実際、バワーズは、オレゴン大学とポートラン ド州立大学で、長年、教員養成に携わっていた。 それゆえ、著作においては何度となく教員養成へ の期待を語る。教員養成にかかわる大学教員や、 現職教員に向けて、文化的な側面で「批判的=反 省的」な姿勢を持てというメッセージを提示す る。つまり、彼の関心は、子どもたちに教える教 員をどのように育てるか、また、すでに子どもた ちに教えている現職教員にどのように「批判的= 反省的」思考を促すかというところにある。換言 すれば、子どもたちに環境教育の名のもとに、何 をどのように教えるのかというレベルではなく、 環境教育を担当する教員をどのように育てるの か、そして、その教員を養成する大学教員や現職 教員を指導する者をどのように思想的な面で刺激 するのかに関心を抱いているといえよう。

\section{2. バワーズの業績の概要}

主として 1990 年代半ば以降、古くは 1969 年か ら今日（2008年）に至るまで、バワーズは、本 論文でとりあげる環境教育に関する著書を含め、 環境や教育、エコロジーに関連する 15 冊の著書、 ならびに多くの論文を執筆している。その数は海 外の環境教育学者のなかで傑出しているといえよ う。

1993年、バワーズは次の 2 冊の著作、すなわち、 『教育・モダニティ・エコロジカルな義務の回復 に関する批判的エッセイ』(Bowers 1993a)、お よび、『教育・文化的神話・エコロジカルな危機 一梁い変革に向けて』（Bowers 1993b）を続けざ まに刊行している。これら 2 冊の著作にも彼の「持 続可能な文化に向けての環境教育」論が垣間見え るが、環境教育に関するまとまった著作として
は、1995年の『エコロジカルな意味で持続可能 な文化に向けての教育 - 道徳教育、創造性、知性 をはじめとする現代の正統派概念を再考する』 (Bowers 1995a) が挙げられる。以下、この著作 を『持続可能な文化に向けての教育』と略記する。 この著作のエッセンスは、「エコロジカルな展望 に向けて」(『教育哲学に関する批判的対話』所収) （Bowers 1995b）に収められているが、そこには 「生存の可能性に対する答えは、前近代的文化に ある」（Bowers 1995b）という端的な指摘が見ら れる。

『持続可能な文化に向けての教育』刊行の 2 年 後の1997年にも、『否定すべき文化一環境運動に は、大学と学校公教育を改革する戦略がなぜ必要 となるのか』（Bowers 1997）を出版している。 この著作では、学校において持続可能な文化が教 育の対象になっていないことが徹底的に批判され ている。サブタイトルにあるように、大学や学校 公教育を変革しなければ環境教育は成功しないこ とを強調している。しかし、それは『持続可能な 文化に向けての教育』の延長線上のものであり、 目新しい主張や理論は見当たらない。

また、2001年にも、バワーズは『エコロジカ ルな正義と共同体に向けての教育』（Bowers 2001）を出版し、科学主義と技術主義が横行す るなかで、教育改革に携わるものたちは、「環境 公正 (eco-justice)」の教育学を目指すべきであり、 環境レイシズムと消費社会のライフスタイルに代 わる共同体を生み出す必要性があり、そのため に、教員養成カリキュラムにおける変革が必要な ことを述べている。しかし、理論的展開が共同体 の再生といった面において斬新であるとはいえ、 『持続可能な文化に向けての教育』の域を出ては いない。

ともあれ、以上に取り上げた著作を一瞥するだ けでも、1990年代の著作において、バワーズは 現代文化に否定的な目を向け、エコロジカルな正 義が実現された持続可能な社会を構築するため に、文化という側面に注目し、学校教育の根底的 な変革を求め続けていたことがわかる。

多くの著作のなかでも、1995年の『持続可能 
な文化に向けての教育』はバワーズの環境教育に 関する代表作であると考えられる。なぜなら、そ れ以前の 2 冊では概念整理が十分にできておらず、 他方、以後の 2 冊は、主題が環境教育から別の領 域に広がる傾向があるからである。しかも、バ ワーズの「持続可能な文化に向けての環境教育」 論の主たる主張は、上記の 5 冊の著作のほか、他 所でも繰り返しなされている1)。これらの点から、 この著作でまとまりのある理論が完成していたと 考えられる。

これまでのバワーズの主な主張については、 Bowers（1997）およびBowers（2001）における 主張を明らかにしたものに、Horwood（1998）、 Shibuya (1998)、Jucker (2002)、Edmundson （2004）などがある。90年代以降のバワーズの著 作（1993b；1995a；1997；2001）に共通する主 張に言及したものとして、Gruenewald（2003） が挙げられる。しかし、1995年の代表作におけ る主張を詳しく整理した成果は限られている。そ こで、本稿においては、以下、而において『持続 可能な文化に向けての教育』に依拠し、筆者らが 定めた視点でバワーズの論をまとめる。

\section{III「持続可能な文化に向けての環境教育」論の 三つの基本的主張}

\section{1.「持続可能な文化」論}

「持続可能な文化に向けての環境教育」論を構 成する三つの基本的主張のなかでその中心となる ものが「持続可能な文化」論である。

『持続可能な文化に向けての教育』において、 バワーズは、18世紀の啓蒙主義思想の確立以降、 伝統社会に受け継がれてきた文化的基底が、現代 社会をリードしている科学技術と産業社会の発展 によって、ほとんど省みられることがなくなった という。また、内実が何であれ「変化」をよいも のとする「進歩」主義と消費中心主義と一体と なった産業主義が、生態系を危機に陥れたと主張 する。そして、技術革新によって、経済成長と資 源開発を続けながら、環境問題が解決できるとい う科学技術的楽観主義を強く批判している。

したがって、問題解決の道として強調されるの
は、エコロジカルな持続可能性を内在させると彼 が考える「持続可能な文化」である。具体的には、 クワキトル、アボリジニ、バリなどの「伝統文化 (traditional cultures)」を例として挙げている。 これらの「伝統文化」とは、「西洋近代文明接触 以前の文化」であり、「時代を溯って、人間を自 然から完全に切り離し、比類なきまでに特権を付 与された理性的なものとして人間を確立した近代 以前の文化」(Bowers 1995a:5）である。

こうした文化に言及する際、バワーズは『持続 可能な文化に向けての教育』や他の著作で「原住 民文化 (indigenous cultures)」や「非西洋文化 (non-western cultures)」という表現も用いる。 しかしながら、「生物圈を構成する自然のシステ ムの環境容量とうまくバランスをとって自然と共 存できる過去の文化」(Bowers 1993b) であると いう意味で、本稿では具体的な内容を伴う場合に は「持続可能な伝統文化」(Bowers 2001) とい う用語を使うことにする。「持続可能な伝統文化」 集団は多種多様だが、そこに内在するエコロジカ ルな知恵に共通の型を認識し、それを文化的学習 の礎に据えることが重要であるとバワーズは言う。

彼は、現代社会の生態系の危機とは、部分的で はあると断るものの、文化的価值と信仰の危機で あると主張し、人間の欲望が増大する一方、自然 が持続可能な状態から遠ざかっていく現在の状況 を生み出しているものは文化的な問題であると考 える。したがって、産業革命以降の「西洋近代文 化」が生態系の危機を生み出したのであり、現代 の文化をそうした問題を生じさせることのない 「伝統文化」に引き戻すことで生態系の持続可能 性が保証されると主張する。

このようにバワーズは「文化」という言葉を用 いて環境の問題を把握しているが、それは言語 コードである一連の「根源的なメタファー」とも 言い換えられる。それは、文化とは異なり、ライ フスタイルや価值観などの具体的内容を伴わない メタファーである。しかし、そうした「メ夕 ファー」が現代人の思考を制約しており、それ自 体には「批判的＝反省的」な目を向けられないと 指摘する。 
バワーズによれば、ここでいう「根源的なメタ ファー」とは、メタ・シェマー世界を認知したり 外界に働きかけたりする土台となる内的な枠組の メタレベルの枠組みーであり、幅広い文化的な経 験についてのアナロジックな思考過程の枠組みと なるものである。そうした「根源的なメタファー」 は、しばしば、文化的集団の「神話的な物語」や、 あるいは経験を強く呼び覚ます強い喚起的経験に 基づいているという（Bowers 2001）。

たとえば、バワーズによれば、家父長制と人間 中心主義も、聖書の創世記にさかのぼるような 「根源的なメタファー」である。直線的進歩概念、 進化と経済の偏重主義、即ちマルクス主義的にい えば、革命を犠牲にしてまで、過度の物質的な生 活の向上を求めること、および、自律的な個人、 といったものも同様であるという。

バワーズの主張の主眼は、思考とは本来「メ夕 ファー」によって支配されているので、ある文化 的集団が有する言語によって考えることが可能に なる内容だけを、その文化の構成員は考えている にすぎないという点にある。すなわち、文化にも 言語にも縛られずに私たちは枠組みのない思考を 自由にめぐらせているように思えるが、実は文化 や言語といったメタ・シェマのなかで考えている に過ぎないとバワーズは考える。

それゆえに、バワーズは、ニーチェ（Nietzsch. F W : 1844-1900)やハイデガー (Heidegger. M : 1889 - 1976）などを援用して、昨今の教育改革 の行動指針も、言語によって既にコード化されて 隠され、自明視されている文化的な仮定に基づい ているので、首尾よく行かないと考え、これを例 証しようとする。

こうしたバワーズの考えを踏まえて言えば、社 会変革のための環境教育も、「文化」や言語といっ た「根源的なメタファー」の使用をラディカルに 反省しなければ、効果がないことになる。批判的 教育学も、資本主義的なものに基礎づけられた社 会について批判を繰り返してはいるが、変化を起 こそうとする際に必要とされる「根源的なメ夕 ファー」が、いまだに環境問題を産み出すような ものである限り、「ダブルバインド状況」に陥り、
変化を起こすことはできないのである。

バワーズは、環境教育の教員養成にかかわる教 育者たちも、生態学的な危険性の根底に横たわる 文化的な根本原因を無視しているばかりではな く、環境をさらに悪化させる思考パターンの再強 化に手を貸しているという。そのことを明確にす るために、「伝統文化」論や「根源的なメタファー」 論を展開して、思考の制約性について注意を喚起 しているといえる。

\section{2. 反「進歩」論}

『持続可能な文化に向けての教育』において、 バワーズは「守旧的 (reactionary)」な立場をとる。 この「守旧的」という言葉は、現代の社会制度や 文化を守る保守主義という意味ではなく、「西洋 近代文化」以前の文化を維持するという独特の意 味で使われている。「守旧的」思考と表現しても よいが、本論文では用語としての分かりやすさを 優先して、反「進歩」論という用語でバワーズの 論を捉えたい。

バワーズによれば、近代技術に基づく消費主義 的な文化を再考する際、今まで当然視してきたさ まざまな前提条件、ないしは「根源的なメ夕 ファー」をも見直す必要性に迫られる。なかでも、 無批判に「進歩」を善なるものとみなす思想、す なわち「進歩（変化）主義思想」を見直すことが 必要であると考えている。

現代社会においては、西洋近代社会の神話とし て「変化 (change)」は一直線の「進歩」であって、 経済発展や技術開発は善ということが前提となっ ている。科学的・技術的な、そして産業社会の「進 歩」が善いものであるという当然視された神話 が、疑われることなく、世代から世代へと受け継 がれており、それが環境問題を生んでいることこ そが問題であるという。

バワーズの意図するところは、「進歩」を無前 提に善いものとみなす文化から、伝統的性格を有 しエコロジーを中心とする定常化した文化に移行 させることにある。彼は、「現代の価值と行動パ ターンがどれほどエコロジカルな危機に関係して いるかを認識している公教育の教員や大学教授は 
わずかである」として、「環境を意識したグルー プは、教育システムのなかで何が教えられている のかについて異議申し立てをする必要がある」 （Bowers 1997）とも述べている。バワーズは、 環境教育によって持続可能な文化に移行する際、 「進歩」それ自体を吟味せずに推進する学校教育、 ないしは、「進歩」とは善いものだと無批判に教 える学校という場所に問題があると、「批判的 = 反省的」な目を向ける。すなわち、学校が環境改 革のフォーラムになることを一方では期待しなが らも、他方で、学校教育が科学技術的楽観主義を 生み出すことに警告を発しているのである (Bowers 1995a：3)。

バワーズは、長期的な文化的・生態学的な存続 を果たしえるかどうかは、持続可能な形態の知識 と価值観をどのように蓄積、伝達、更新するかと いう私たちの人間としての「集合的な能力 (collective ability)」にかかっていると述べる (Bowers 1995a：135)。「集合的な能力」と表現 しているが、それは市民的な合意を経た上で、教 育政策に反映されて発揮されるようなものではな い。

バワーズによれば、伝統的な文化集団といった ものの持続可能な価值観を伝えるものは、たとえ ば、現代文化の言語コードに支配されない伝統文 化の長老たちの「語り（ナラティブ）」といった ものである。集団が共有する価值観を長老が語る ことによって伝わることを前提としている。それ ゆえ、現代の公教育のなかでの紙に印刷されたも のや権威づけられた情報による「教え＝学び」で は、こうした持続可能な形態の知識や価值観は伝 わらないことを示唆しているのである。

換言すれば、「持続可能な伝統文化」集団の日 常生活に織り込まれた自然な態度として、「進歩」 を必ずしも善いものであるとみなさない価值観や 道徳規範が存在しており、「語り」によって、そ れが伝達されると考えている。しかも、科学的根 拠に基づく合理的説得を通じて、エコロジカルな 意味で持続可能な文化に包摂される道徳や規範、 考え方が育つことはないと、バワーズは考えてい る (Bowers 1995a : 23-40)。

\section{3.「ホリスティック」な視点}

バワーズがその重要性を主張する「ホリス ティック」な視点とは、人間は、自然や地域、土 地、それらとは切り離しがたい文化や伝統と一体 であるという理解に基づくものである。

バワーズは、「レオポルドのいう『土地倫理』 を発展させない文化は滅びる」(Bowers 1995a： 23）と断言する。近代的個人は自分の力で可能 なことは実現させようと考える傾向が強いため、 土地 (環境) の制約条件などを無視して、独善的 に生産消費活動を進めてしまう。しかし、土地や 自然とのつながりを忘れてはならないという警告 を発しもするのは、一方で、経済活動の自由に 走って持続不可能な社会と文化に逢着してしまう という反省があるためである。また、政治的自由 主義に走り、個人の価值や権利などを信じるあま りに、自然とのつながりや資源の限界などを無視 する傾向があるとの反省があるためである。要す るに、ホリスティックな視点とは、自由主義や個 人主義への「批判的 $=$ 反省的」視点と表裏一体の ものである。

なお、バワーズの「ホリスティックな視点」と は、独立し自律した個人に価值を認めず、単位と して包括的に社会や文化を捉える見方である。文 化から切り離され、合理的・自律的で、客観的知 識の「正当性」の審判者としての「自己」像を否 定し、個人中心主義から脱却し、生態圈における 生命体との共存を図ろうとする。通常使われる 「ホリスティック」の語義とは異なる。

バワーズの「ホリスティック」な視点において は、自由主義の理念の代わりに、非人間中心的な 形の保守主義（守旧主義）を採用すべきというこ とになる。現代社会よりも自然システムと調和し た生活によって人間生活の質を向上させる共同 体、農業、労働およびその他の人間の営みの形態 に関係する立場という意味で、バワーズは「文 化·生命保守主義 (cultural/bio conservatism)」 とも言うべき立場をとる。人間中心主義を部分的 に否定し「進歩」や「変化」を積極的に望まない という意味で、バワーズは自由主義も否定する。 エコロジカルな見地からみて持続可能な文化的パ 
ターンを尊重し向上させることは、個人中心的な 自由主義の表現から解放されなければならないと いう。たとえば、何かを決定するとき、7世代先 の子孫を念頭に置くことによって連続体の一部と しての生命感覚を捉えるという北米先住民族の習 慣を例にとりあげ、全体論的かつ世代を超えると いう意味での「ホリスティック」な立場に立つ (Bowers 1995a : 39, 184-196)。

また、バワーズによれば、多数の先住民文化が、 人間はもっと大きな生命共同体の一部であること を理解していたという。そして、そのような先住 民族の生命共同体に対する参加的かつ相互依存的 な関係の感覚は、熊、狼、鮭、トウモロコシなど にもおよび、生命の基本形態を理解していたと主 張する。こうした自然界のリズムへの参加という 感覚は、語り、歌、視覚芸術などの精神言語の発 達を通じて祝福されたという。バワーズは、道徳 教育と環境教育の形態は、今、現代の社会と文化 に正当性を与えているものとは根本的に異なるイ デオロギー的かつ認識論的志向に基づくべきであ ると主張するのである（Bowers 1995a：38-40）。

\section{$\mathrm{N}$ 考 察}

II およびIIIでまとめたバワーズの基本的主張を ふまえて、考察したい。

\section{1. 全体的考察}

昨今、環境関連の諸科学において、多角的に持 続可能な社会の構想が練られているとはいえ、環 境教育の研究者による持続可能な社会像や文化像 に関する先行研究は多いとはいえない。そのよう な背景があるなかで、バワーズは、環境教育の研 究者として「持続可能な文化」に焦点を合わせて 持続可能な社会を具体的に構想したという点で評 価できる。たしかに、バワーズの論には難点もあ るが、環境教育の理論構築の手がかりとなる意義 深い示唆を多く含んでいる。

基本的には、「持続可能な文化に向けての環境 教育」論の全体の趣旨は明快で、論理的で一貫し ており、鋭い指摘を数多く含んでいる。バワーズ の「批判的 =反省的」思考法は、対象に不当な攻 撃を加えたり、論拠もなくその欠点のみを取り上
げたりするといった性質の悪いものでもない。

簡潔にまとめるならば、バワーズは、持続可能 な社会とは、「持続可能な伝統文化」社会と類似 したものであると考えている。そうした文化集団 に回州することによって持続可能性が保たれると 主張する。加えて、彼は、西洋近代文化を基盤と した環境教育思想の制約性について注意を喚起 し、妥協のないラディカルな社会変革を求めてい る。「持続可能な文化に向けての環境教育」論は、 「持続不可能な文化」を再生産する装置としての 学校教育への反省を促し、しかも、現代の西洋文 化の価值観や認識論的枠組み以外の思想からも根 本的に環境教育を再考しなければならないことに 気づかせてくれる点で評価できる。

ところで、フィエンは、多くの環境教育研究者 の理論を援用しながら、社会批判的な立場から構 造的な社会変革を求める「批判的環境教育 (critical environmental education)」論を示した (Fien 1993)。「批判的環境教育」論は、「環境の なかでの教育 (education in the environment)」 「環境についての教育 (education about the environment)」「環境のための教育 (education for the environment)」と分類されるなかで、「環 境のための教育」をその軸とするものであると理 解できるが、バワーズもこうした「批判的環境教 育」論を展開していたといえる ${ }^{2)}$ 。

「批判的環境教育」論と通底する「エコ教育学 (Öko - Pädagogik)」の立場、および、その後も こうした動きを主導したドイツの環境教育論者 デ・ハーン（de Haan, G：1951-）らの論を研 究した若林身歌は、「エコ教育学」が、政府や国 際的な諸団体がこぞって推進するいわゆる社会的 認知を受けた主流派の「官製の環境教育」の対抗 勢力であったことを明らかにしている（若林 2003)。バワーズも同様に、部分的には「官製の 環境教育」の対抗勢力であったと言える。

仮に、バワーズの論を、(1)環境教育のカリキュ ラムや教材に、現代文化を見直す材料となる「伝 統文化」に関する文化的学習を持ち込むべきであ り、しかも、(2)環境教育の教員養成においてその ような文化的視点を入れるべきである、という主 
張として受け止めるなら、それは例外的な主張で はないといえる。たとえば、ユネスコのウェブサ イトによって世界中で使用可能となった教員研修 用教材において、「先住民族の知恵と持続可能性 (11章)」という一章が設けられており、先住民 族の「もうひとつの知識体系」を学ぶ意義が示さ れている（ユネスコ 2005）。持続可能性の高い文 化を参考にして、これからの持続可能な社会と環 境教育を構想すべきであるという程度の意味で 「持続可能な文化に向けての環境教育」論を理解 するならば、その見解は斬新なものではない。

バワーズは、「持続可能な社会、文化」を非西 欧の小さな土地（地域）に根ざした伝統を前提と するものと捉え、環境面でも文化面でも「変化」 のないことを重視する。そして、この原理的主張 に妥協を許さないため、社会変革を担う自律的個 人が育つことや、差別や支配にかかわる現存の諸 問題への社会批判に重要性を認める立場も、現在 の消費文明、産業文明を生み出したものと同根で あるとして否定してしまう。こうしたバワーズの 姿勢は、バワーズ（2005）と、この論文によって 否定された立場からこの批判に反論する Houston ほか（2005）とのやり取りに顕著に表れている。

\section{2. 批判的考察}

バワーズの「持続可能な文化に向けての環境教 育」は、全体的には評価できるが、次に示す5つ の難点を含むものである。

第一に、「伝統文化」に依拠して「持続可能な 文化」のモデルを提示しようとするバワーズの試 みは、説得力を持つものになっていない。バワー ズは、近代社会に住むわれわれが目指すべき方向 を示すものとして、アボリジニやクワキトルと いった人びとに関する文化人類学的な知見を紹介 している。しかし、これらの人びとの生活のあり 方が地域の環境特性や歴史的に培われた民族の文 化特性に深く根ざすものでありバワーズ自身もま さにこの点を強調しているにもかかわらず、一般 化を通じて、われわれ自身の指針となる「持続可 能な文化」のモデルとなることを示すまでには 至っていない。
ただし、エコロジカルな意味で持続可能性の高 い文化といったものは存在すると推定できる。そ のような文化の実現を目指して教育を行うべきで あるという教育目的論まで否定する必要はない。 持続可能性の高い文化が存在するという仮定は、 それを保証する文化的な要素がいくつか抽出でき るという意味で理解するならば、有意義である。 持続可能な文化が存在すると仮定すれば、それ は、地球規模と地域内の二つの意味での環境容量 内で、定常的な社会状況-すなわち、(1)総人口と 人口密度の定常化、(2)生産 $=$ 消費の総量の定量 化、および、現在と比較対照した消費の質の低下 とその状態の定常化、(3)科学技術の定常化-を実 現する文化であると推定される（Bonnett 2004）。 こうした持続可能な文化の内容や必須要素につい ての議論を沸騰させるという意味では刺激的な論 である。

ただし、そのような文化と社会を実現するため には、多大な時間と労力を要する意思決定のプロ セスと環境教育政策の実施のプロセスが必要とな る。それについては第三の疑問点でまとめるが、 そのような文化と社会における環境教育とは、定 常文化（伝統文化）の単純再生産を使命とするも のになると予測できる。そのような環境教育は、 持続可能な社会を創造するプロセスにおける環境 教育とは異なるものである。環境教育は、定常社 会に向けてのプロセスを推進する教育なのか、あ るいは定常状態を安定化させる固定的な教育なの かという疑問を検討し、何がその本質的役割なの かを考察しなければなるまい。だが、バワーズは、 持続可能な定常化社会における環境教育とそのよ うな社会への变化を促進する環境教育との違いを 認識していない。

第二に問題となるのは、「持続可能な文化」論 の展開において、バワーズが豊かな個人の存在の あり方やエコロジカルな自己のあり方について考 察していないという点である。

バワーズの「持続可能な文化」論で実際に例示 されている前近代文化の慣習や価值観について は、あらためて洗い直す必要がある。だが、バワー ズの論を丁寧に巡れば、彼の言う「伝統文化」は 
狩絧・採集の世界の文化であり、呪術師や長老と いったものが権力をもつ世界であることがわかる。

その場合、歴史と風土により形作られる各々の 「伝統文化」の価值観に基づけば、生活習慣や慣 習などにおいて非人道的で権威主義的な側面を有 する社会もあるに違いない。全体として環境面で 持続可能であるからといって、個人の存在の豊か さなど認められない社会もあるだろう。そうした 社会では、近代以降の市民社会の発展において獲 得された個人の権利などは存在し難い。人権概念 が発達して、自由な言論を背景とする民主主義的 社会とは異なり、個人に価值が置かれない文化を 私たちは受け入れることができるのだろうか。

持続可能な社会が構築できるとすれば、そのな かで人間のひとりひとりがどのように自己と折り 合いをつけ自己認識できるとともに他者とも豊か な関係性を築くかといった人間関係における自己 認識システムの発達や進歩が必要である。エコロ ジカルな自己存在、関係性としての自己を含め、 個人の存在の豊かさやこれまでに獲得した人権な どの基本的な概念とともにそうした持続可能性を 実現しなければならない。この点において、「持 続可能な文化」論は魅力に欠ける。

第三の問題は、「持続可能な文化に向けての環 境教育」論が、その変化に必要なプロセスに十分 に目を向けていない点にある。

仮に、「持続可能な文化」が存在しうると想定 しても、公正で民主的な手続きを踏むことなし に、その文化への移行を実現することは不可能で ある。現代の民主主義的な社会はそれを許さな い。ある種の権力者が、その文化集団の成員に対 して、これまでの禁欲の伝統を、理由や情報、合 意を抜きにして権威主義的に強制することは不可 能であるばかりか、望ましくもない。

たしかに、人類が生き延びることが可能かどう か、持続可能性の高い文化に移行できるかどうか は、環境の危機を目前にして、社会が押し付ける 必然的な拘束に、個人がどの程度順応できるか、 どれほどの速さで変化できるかにかかっているだ ろう（Horkheimer 1967）。生き残るためには、 現在人間が直面している生をめぐる混乱した状況
に対して、今すぐにでも適切な反応形式で応答 し、人間が変わる必要がある。生存という結果が 優先されるのであれば、そのプロセスをできるだ けスムーズなものにする必要は認められる。

それでも、個人の環境問題の理解のプロセスや 他者との合意形成のプロセス、政策実現のプロセ スを待たずに、環境教育においてのみ持続可能性 の高い文化に基づく考え方や行動をとるように強 制することはできない。バワーズはたしかに「官 製の環境教育」論者ではない。だが、かといって 市民性（citizenship）や、市民の参加と合意のプ ロセスを重視している民主的な環境教育論を展開 してはいない。民主的で公正な社会変革のプロセ スを重要視する立場からは受け入れがたい主張で ある。

もちろん、バワーズは、持論を展開するなかで、 新人の教員の養成に新たに文化的側面を付け加え るだけではなく、現職の教師の知識と能力を刷新 し、教師教育カリキュラムを作成しなおすことの 必要性は認識している。世界中の教育学部におい て、持続可能な文化といったものを学びなおすカ リキュラムが必要となるのだろうが、その手続き には触れられていない。この点でもやはり、プロ セスが抜け落ちているといわざるを得ない。

第四の疑問点は、反「進歩」論に関するもので ある。すでに第一、第二の疑問点で示したことも 含め、まずはバワーズの言う意味での「進歩」を 止めた社会が本当に持続可能かどうかについて疑 問が残る。

また、人間存在のあり方について豊かさを求 め、よりよい共同体を作るという点での変化は止 めようとしても止められないのではないだろう か。ただし、消費者中心の産業社会の進歩や、科 学技術の進歩に関しては、「技術的にある種の進 歩は可能だが行わない」という立場をとることが できる。どのような点で「進歩」を停止し、どの 点では「進歩」を認めるのか。そのような課題と してバワーズの主張を引き受けるならば生産的で あろう。重要なことは、あるべき「進歩」の内実 を丁寧に検証することであって、すべての「進歩」 を停止することではない。 
最後に、バワーズの独特な「ホリスティック」 論にも、第五の疑問としてまとめられる多くの問 題がある。一般的なホリスティック思考とは異な り、バワーズの「ホリスティック」論の基盤には 前近代社会への羡望が含まれている。この「ホリ スティック」な見方を進めると、集団の重視と主 体としての個の消滅を招く可能性がある。

少なくとも現代の日本社会においては、個人と は自立・自律した精神的な存在であり、至上の価 值を担う存在である。このように個人が共同体に おいて至上の価值とされている場合、「ホリス ティック」論は多くの矛盾や危機を引き起こす。 他方、ひとつの全体としての共同体に超越的な価 值が見出される場合、それはバワーズの用語では 「ホリズム」であるが、一般的な用語では「全体 主義（totalitarianism）」に近いものとなる。この 場合、全体に対する責任によって個の生活におけ る必要や要求が断念され、全体のための自己制限 （自己犠牲）が強制されることになる。

一方、プロセスが公正で妥当なものであれば、 個の否定には至らない。むしろ、独立した個であ るからこそ、全体を理解し、そこから生じる制約 条件に自発的に従うこともできる。持続可能な社 会を実現する環境教育論が踏まえるべきは、バ ワーズの偏狭な「ホリスティック」論ではない。 フィエンは、批判的教育学はホリスティックな エートスにもっと目を向けるべきだという批判 を、部分的に受け入れているが（Fien 1993）、そ れはバワーズの独自の「ホリスティック」論では ないことに留意すべきである。

総じて言えば、仮に「持続可能な文化」を注入 して、環境の持続性という課題を解決することを 優先する環境教育を構想するとしても、持続可能 な社会像をより明確にするとともに、そうした社 会に移行するための市民性の育成と市民的合意の プロセス、個人のあり方など解決すべき問題は残 る。それはバワーズの「持続可能な文化に向けて の教育」論に限られた課題ではない。一般的な環 境教育においても同様に問題になる。

バワーズは持続可能な社会をどう構想するかと いう課題を突きつける。その課題には真摰に向き
合う必要がある。同時に、バワーズの論によって 導き出される新たな問いは、環境教育は、どの程 度、環境問題を生み出したと考えられる文化と当 然視されている価值観にかかわり、どの程度まで それを左右する影響力を持つかという程度問題で ある。環境教育が文化に対するスタンスをどうと るのかという問題といってもよい。もちろん、手 続きを抜きにして、エコロジカルな意味での持続 可能性の高い文化を注入する教育を施すことにつ いては慎重であるべきである。だが、持続可能 性の高い社会と文化に移行するためのプロセスを 重視する環境教育を構想するとすれば、そのプロ セスに参加できる市民性を育成するとともに、民 主的で公正な持続可能な社会の構築に参加する市 民を育成する課題が立ち現れる。程度問題の解決 については現段階ではさておくとしても、少なく とも、持続可能性の高い社会に向けて社会的変化 を促進するための市民性を培い、そのプロセスに 貢献する環境教育を構想する必要がある。

\section{註}

1 ）同書の引用部分は複数あるため、引用した場 合、および、数頁にわたる箇所をまとめた場合 には、(Bowers 1995a：1)、(Bowers 1995a： 1-10）という形式で該当頁を表記した。

2 )「批判的環境教育」論はきわめて多様である。 フィエンとバワーズ、デ・ハーンらも含め、批 判的教育学から影響を受けたその他の環境教育 の研究者らの議論も含めて、「批判的環境教育」 論の異同も明確にしなければならないが、それ は今後の課題としたい。

\section{引用文献}

- Bonnett, M, 2004, Retrieving Nature: Education for a Post-Humanist Age, Blackwell Publishing, $1-12$.

- Bowers, C. A. 1991, The anthropocentric foundations of educational liberalism : Some critical concerns, Trumpeter, 8-3, 102-107.

- Bowers, C. A. 1993a, Education, Cultural Myths, and the Ecological Crisis : Toward Deep Changes, 
SUNY Series in philosophy of Education. Albany, N. Y.: State University of New York Press.

- Bowers, C. A. 1993b, Critical Essays on Education, Modernity, and the Recovery of the Ecological Imperative, New York: Teachers College Press, 10.

- Bowers, C. A. 1995a, Educating for an Ecologically Sustainable Culture : Rethinking Moral Education, Creativity, Intelligence, and Other Modern Orthodoxies, Albany : State University of New York Press.

- Bowers, C. A. 1995b, “Toward an Ecological Perspective”, Critical Conversations in Philosophy of Education, Edited; Wendy Kohli, Routledge, New York, 310-323.

- Bowers, C. A. 1997, The Culture of Denial : Why the Environmental Movement Needs a Strategy for Reforming Universities and Public Schools, Albany: State University of New York Press.

- Bowers, C. A. 2000, Let Them Eat Data : How Computers Affect Education, Cultural Diversity, and the Prospects of Ecological Sustainability, Athens : University of Georgia Press.

- Bowers, C. A. 2001, Educating for Eco-Justice and Community, Athens: University of Georgia Press, 38-45.

- Bowers, C. A. 2005, How Peter McLaren and Donna Houston, and Other "Green" Marxists Contribute to the Globalization of the West's Industrial Culture, Educational Studies, 37 (2), 185-195.

- Edmundson, J. 2004, Book Review (Educating for Eco-Justice and Community), Educational Studies, 36 (1), 118-123.

- Fien J. 1993, Education For The Environment : Critical Curriculum Theorising and Environmental Education, Deakin University, 7-8, 96-97. (石 川聡子・石川寿敏・塩川哲雄・原子栄一郎・渡
辺智暁訳, 2001, 『環境のための教育 批判的 カリキュラム理論と環境教育』, 東信堂, 東京, 20-21, 167-169.)

- Horkheimer, M. 1967, Kritik der instrumentellen Vernunft, Frankfurt a. M. S. 95.

- Horwood, B. 1998, Reviews (The Culture of Denial), Canadian Journal of Environmental Education, 3, http://www.uleth.ca/edu/ research/ictrd/cjee/(2009年6月6日確認), the TLTR\&D in the Faculty of Education at the University of Lethbridge.

- Houston, D. McLaren, P. 2005, Response to Bowers: The 'Nature' of Political Amnesia : A Response to C. A. 'Chet' Bowers, Educational Studies, 37 (2), 196-206.

- Jucker, R. 2002, Book Review (Educating for Eco-Justice and Community), The Trumpeter, 18 (1).

- Shibuya, E.1998, Book Review (The Culture of Denial), URL: http://www.h-net.org/reviews/ (2009年 5 月 28 日確認), Michigan State University.

・今村光章, 2003, 「環境教育ダブルバインド論 の視座とその射程」, 山嵪高哉編『応答する教 育哲学』, ナカニシヤ出版, 京都, 182-200.

- 今村光章編, 2005 , 『持続可能性に向けての環 境教育』, 昭和堂, 京都, $210 \mathrm{pp}$.

・教育思想史学会編, 2000, 『教育思想事典』, 勁 草書房, 東京, 185.

・杉本卓, 2003,「訳者あとがき」, C. A. バワーズ, 杉本卓・和田惠美子訳, 『コンピュータを疑 え- 文化・教育・生態系が壊されるとき』 (Bowers 2000), 新曜社, 東京, 228.

・ユネスコ，阿部治ほか監訳，2005，持続可能な 未来のための学習, 有斐閣, 東京, 181-192.

・若林身歌，2003，ドイツの環境教育論議に関す る基礎研究-「エコ教育学」の分析を中心に-, 京都大学大学院教育学研究科紀要 49, 142-154. 